\title{
INOVASI KATAMA (KADER TANGGAP ANEMIA) DI DESA WAY DADI, SUKARAME, BANDAR LAMPUNG
}

\author{
Astriana ${ }^{1}$, Ana Mariza ${ }^{2}$ \\ ${ }^{1,2}$ Dosen Prodi Kebidanan Universitas Malahayati \\ Email : ashtry.hs@gmail.com \\ anamariza@malahayati.ac.id
}

\begin{abstract}
ABSTRAK
Anemia pada ibu hamil dihubungkan dengan meningkatnya kelahiran prematur, kemtian ibu dan anak dan penyakir infeksi. Anemia defisiensi pada ibu dapat mempengaruhi pertumbuhan dan perkembangan janin. Paling tidak setengahnya disebabkan kekurangan zat besi. Ibu hamil dinyatakan anemia jika hemoglobin kurang dari $11 \mathrm{mg} / \mathrm{dL}$. Proporsi anemia pada ibu hamil di Indonesia $37,1 \%$. Salah satu inovasi sebagai upaya preventif preeklampsia adalah launching KATAMA (Kader Tanggap Anemia). Tujuan kegiatan ini adalah masyarakat mengerti faktor risiko, tanda bahaya dan upaya pencegahan anemia. Materi yang disampaiakan dalam penyuluhan meliputi definisi anemia, faktor risiko anemia, tanda gejala anemia, upaya pencegahan anemia, manfaat mengonsumsi jambu biji merah pada ibu hamil, serta kapan waktu mengonsumsi jambu biji merah pada ibu hamil yang dianjurkan.
\end{abstract}

Kata Kunci: Kader, Anemia, Ibu Hamil

\section{ABSTRACT}

Anemia in pregnant women is associated with an increase in preterm birth, maternal and child mortality and to disease infections. Deficiency anemia in the mother can affect fetal growth and development. At least half of it is due to iron deficiency. Pregnant women are declared anemic if their hemoglobin is less than $11 \mathrm{mg} / \mathrm{dL}$. The proportion of anemia in pregnant women in Indonesia is $37.1 \%$. One of the innovations as an effort to prevent preeclampsia is the launching of KATAMA (Kader Tanggap Anemia). The purpose of this activity is for the public to understand risk factors, danger signs and efforts to prevent anemia. The material presented in the counseling includes the definition of anemia, risk factors for anemia, signs of anemia symptoms, efforts to prevent anemia, the benefits of consuming red guava for pregnant women, and recommended time to consume red guava for pregnant women.

Keywords : Keywords: Cadres, Anemia, Pregnant Women

\section{PENDAHULUAN}

Anemia adalah suatu keadaan yang mana kadar hemoglobin $(\mathrm{Hb})$ dalam tubuh dibawah nilai normal sesuai kelompok orang tertentu (Irianto, 2014). Anemia pada ibu hamil berdampak buruk bagi ibu maupun janin. 
Kemungkinan dampak buruk terhadap ibu hamil yaitu proses persalinan yang membutuhkan waktu lama dan mengakibatkan perdarahan serta syok akibat kontraksi. Dampak buruk pada janin yaitu terjadinya prematur, bayi lahir berat badan rendah, kecacatan bahkan kematian bayi (Fikawati, 2015).

Hemoglobin merupakan zat warna yang terdapat dalam sel darah merah dan berguna untuk mengangkut oksigen dan karbon dioksida dalam sel tubuh. Hemoglobin adalah ikatan antara protein, garam besi, dan zat warna. Sebagian besar ibu hamil akan mengalami beberapa tingkat anemia karena zat besi dibutuhkan untuk menghasilkan sel darah merah pada janin.anemia bisa muncul selama kehamilan karena kekurangan asam folat. Saat kehamilan, anemia dapat dicegah atau diobati dengan menggunakan zat besi dan suplemen asam folat.

Anemia merupakan dimana kadar hemoglobin $(\mathrm{Hb})$ seseorang kurang dari $10 \mathrm{~g} / \mathrm{dl}$, sedangkan angka idealnya untuk ibu dewasa berdasarkan standar WHO adalah $12 \mathrm{~g} / \mathrm{dl}$. Badan kesehatan dunia (WHO) melaporkan bahwa prevelensi ibu-ibu hamil yang mengalami defesiensi besi sekitar 35-75\%, serta semakin meningkat seiring dengan pertambahan usia kehamilan. Anemia defisensi zat besi lebih cendrung berlangsung di negara yang sedang berkembang dari pada negara yang sudah maju, 36\% (atau sekitar 1400 juta orang) dari perkiraaan populasi 3800 juta orang dinegara maju hanya sekitar 8\% (atau kira-kira 100 juta orang) dari perkiraan populasi 1200 juta orang.

WHO melaporkan bahwa prevelensi anemia pada kehamilan secara global sebesar (55\%). Sedangkan prevelensi anemia pada ibu hamil di Indonesia tahun 2010 adalah (70\%) atau 7 dari 10 wanita hamil menderita anemia. Prevelensi anemia pada ibu hamil di Indonesia masih sangat tinggi. Tingginya prevelensi anemia antara lain disebabkan oleh beberapa faktor yaitu kehilangan darah secara kronis, asupan zat besi untuk pembentukan sel darah merah yang secara fisiologis berlangsung pada masa pertumbuhan, masa pubertas, masa kehamilan dan menyusui.

Pada ibu hamil, zat besi memiliki peranan yang cukup penting untuk pertumbuhan janin. Selama hamil, asupan zat besi harus tambah mengingat selama kehamilan. Kekurangan zat besi sejak sebelum kehamilan bila tidak diatasi dapat mengakibatkan ibu hamil menderita anemia. Kondisi ini dapat meningkatkan resiko pada kematian pada saat melahirkan, melahirkan bayi dengan berat badan lahir rendah, janin dan ibu mudah terkena infeksi, keguguran, dan meningkatkan resiko bayi lahir premature.

Anemia pada ibu hamil dihubungkan dengan meningkatnya kelahiran prematur, kemtian ibu dan anak dan penyakir infeksi. Anemia defisiensi pada ibu dapat mempengaruhi pertumbuhan dan perkembangan janin. Paling tidak setengahnya disebabkan kekurangan zat besi. Ibu hamil dinyatakan anemia jika hemoglobin kurang dari $11 \mathrm{mg} / \mathrm{dL}$. Proporsi anemia pada ibu hamil di Indonesia $37,1 \%{ }^{(3)}$.

Dinas Kesehatan Provinsi Lampung mencatat bahwa kejadian anemia pada 
ibu hamil di Lampung pada tahun 2013 cukup tinggi yaitu berkisar 176.705 $(56,39)$ dari 313,381 ibu hamil ${ }^{(4)}$. Dinas Kesehatan Lampung Tengah mencatat bahwa kejadian anemia pada ibu hamil di Lampung Tengah pada tahun 2012 yaitu 15,39\%.

Menurut sebuah penelitian Yeri esty ningtyastuti salah satu buah yang dapat meningkatkan kadar hemoglobin adalah buah jambu biji merah kandungan dalam jambu biji merah adalah asam amino (triptofan, lisin), kalsium, fosfor, besi, belerang, Vitamin A, vitamin B1, dan Vitamin C. Kandungan mineral yang ada dalam buah jambu biji merah dapat mengatasi penderita anemia (kekurangan darah merah) karena di dalam buah jambu biji merah mengandung juga zat mineral yang dapat memperlancar pembentukan hemoglobin sel darah merah.

Untuk itu dilakukan pencegahan untuk mengatasi anemia atau turunnya kadar $\mathrm{Hb}$ (Hemoglobin) yaitu dengan mengkonsumsi makanan atau buahbuahan yang mengandung zat besi dan vit.c seperti jambu biji merah merupakan buah-buahan dalam kandungan zat besi membantu untuk meningkatkan kadar hemoglobin ibu dengan mengkonsumsi jambu biji merah. Dengan kadar $\mathrm{Hb}$ yang meningkat akan dapat meningkatkan kualitas kehamilan ibu. Ibu tidak mudah lelah dan dapat menghindari resiko perdarahan pada saat persalinan.

Sejalan dengan teori jambu biji merah adalah salah satu buah yang memiliki banyak manfaat. Manfaat jambu biji merah antara lain mengandung vitamin c, menjaga sistem kekebalan tubuh, kaya akan asam folat, mencegah anemia mengkonsumsi jambu biji merah untuk ibu yang sedang hamil akan membantu dalam pencegahan anemia. Bahkan jika kekurangan zat besi selama kehamilan dapat beresiko bagi ibu dan janin, bagi ibu hamil yang terkena anemia dapat terjadi perdarahan saat hamil maupun saat bersalin, lemas dan mudah capek sehingga mengganggu aktivitas sehari-hari. Pada janin dapat menyebabkan BBLR (berat badan lahir rendah) akibat terganggunya pemenuhan nutrisi saat didalam kandungan, lahir premature, dan abortus ${ }^{(5)}$

Dan setiap buah memiliki kandungan gizi yang berbeda. Semakin beragam buah yang dikonsumsi akan semakin baik, sebab semakin lengkap zat gizi dan manfaat yang dapat diperoleh bagi tubuh. Buah jambu biji merah mengandung asam amino, pectin, kalsium, fosfor, zat besi, magnesium, vitamin $A, B$,dan $C$.

\section{MASALAH}

Desa Way Dadi Bandar Lampung, terletak di pinggiran Kota Bandar Lampung Kegiatan ini dilakukan atas dasar belum adanya program edukasi kepada ibu hamil tentang anemia selama kehamilan yang dapat menimbulkan resiko baik pada ibu maupun pada janin. Ibu hamil belum mengetahui mengenai manfaat dari jambu biji merah pada ibu hamil dalam upaya pencegahan anemia dan peningkatan kadar HB selama ibu hamil. Tujuan kegiatan ini adalah meningkatnya pengetahuan dan pemahaman ibu hamil tentang anemia dan pemanfaatan dari jambu biji merah bagi ibu hamil 


\section{METODE KEGIATAN}

Program ini dibentuk dengan melakukan pendataan terlebih dahulu pada seluruh sampel masyarakat Desa Way Dadi Bandar Lampung selama 2 minggu. Setelah itu terbentuklah "KATAMA" sebagai acuannya yaitu ibu hamil dengan anemia. Program ini dilaksanakan dengan melakukan penyuluhan terlebih dahulu dengan para kader Desa Pemanggilan. Metode penyuluhan yang di pakai adalah dengan ceramah mengggunakan lembar balik dan diskusi Tanya jawab. Waktu yang diperlukan dalam penyampaian materi adalah 60 menit. Tahap akhir dari kegiatan tersebut adalah mengukur kembali tingkat pengetahuan ibu hamil dengan memberikan pertanyaan yang sama pada tahap awal. Pertanyaan diberikan secara lisan.

\section{PEMBAHASAN}

Penyuluhan ini dilaksanakan pada tanggal 31 Maret 2021 di Desa Way Dadi Bandar Lampung. Penyuluhan ini diikuti oleh 5 orang perwakilan kader di Desa Way Dadi Bandar Lampung. Pada kesempatan ini kami menjelaskan tentang macam anemia, bahaya anemia, factor penyebab terjadinya anemia, mengenalkan program KATAMA pada ibu kader dengan mengetahui manfaat dari jambu biji merahpada ibu hamil.

Harapannya setelah dilakukan penyuluhan ini para perwakilan kader dapat membagikan ilmunya pada ibu hamil di wilayahnya atau sesama kader lainnya.Sehingga, mereka dapat menolong ibu hamil dengan anemia dan mencegah terjadinya anemia, serta mengembangkan kegiatan yang bersumber pada masyarakat, sesuai dengan kondisi sosial budaya setempat dan didukung oleh kebijakan secara internal maupun lingkungannya yang berwawasan kesehatan.

\section{KESIMPULAN}

Di Desa Way dadi sendiri setelah dilakukan pendataan kesehatan penduduk selama 2 minggu didapati kasus ibu hamil dengan anemia yang beresiko untuk ibu dan janin. Hal ini membuat kami tertarik untuk melakukan upaya preventif lain yang dapat diterapkan sebagai upaya pencegahan terjadinya anemia adalah dengan mengkonsumsi jambu biji merah bagi ibu hamil. Program ini kami namakan dengan "KATAMA".

Program KATAMA yang diikuti olah 5 perwakilan kader di Desa Way Dadi Bandar Lampung berjalan dengan baik. Kader dapat memahami manfaat buah jambu biji merah untuk kesehatan khususnya pada ibu hamil dengan anemia. Selain itu, diharapkan para kader dapat membagikan ilmunya pada masyarakat sekitar ataupun pada kader di desa lainnya. 


\section{Astriana, Ana Mariza}

\section{DOKUMENTASI}
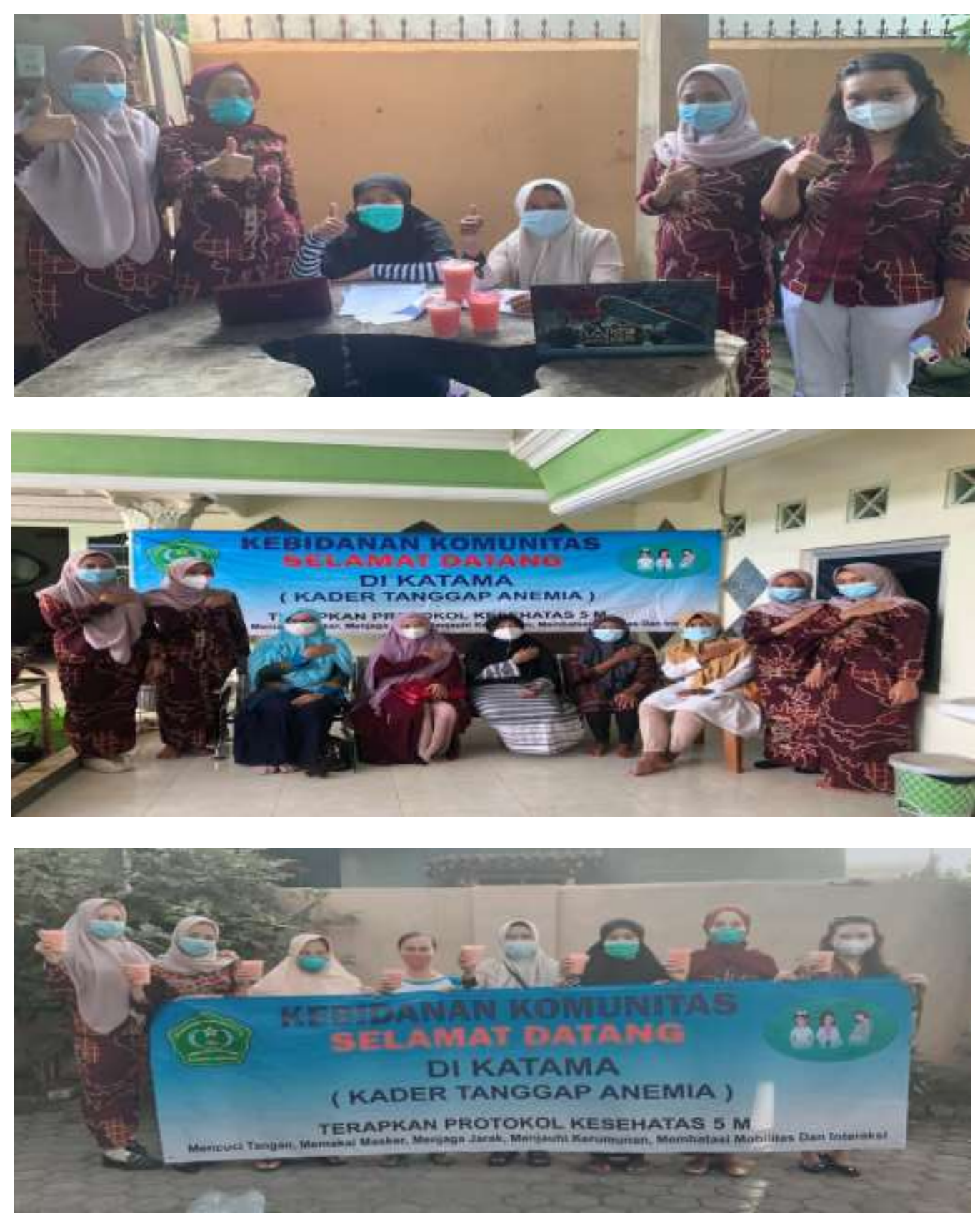

\section{DAFTAR PUSTAKA}

Arisman. (2012). Gizi dalam Daur Kehidupan. Jakarta: EGC.

Bakta, I Made. (2014). Hematologi Klinik Ringkas. Penerbit Buku Kedokteran. EGC

Dalimartha. (2013). Pengaruh Konsumsi Jus Bayam Merah terhadap Peningkatan Kadar $\mathrm{Hb}$ pada Ibu Hamil di Kecamatan Tawangmangu: Kebidanan Akbid YLPP Purwokerto. 
Dinas Kesehatan Provinsi Lampung. (2015). Profil Kesehatan Lampung 2014. Lampung.

Kementrian Kesehatan RI. (2014). Riset kesehatan dasar 2014. Jakarta.

Kementrian Kesehatan RI. (2016). Profil Kesehatan Indonesia 2015. Jakarta.

Manuaba, I. B. G. (2010). Memahami kesehatan reproduksi wanita (2 ed.). Jakarta: EGC.

Manuaba, I. B. G. (2013). Ilmu Kebidanan Penyakit Kandungan dan Keluarga Berencana. Jakarta: EGC.

Naibaho, S. A. (2011). Faktor-Faktor Yang Berhubungan Dengan Kejadian Anemia Gizi Pada Ibu Hamil di Wilayah Kerja Puskesmas Parsoburan Kec. Habinsaran Kabupaten Toba Samosir Tahun 2011. [Skripsi]. Medan: Fakultas Kesehatan Masyarakat, Univesitas Sumatera Utara.

Proverawati, A. (2011). Anemia dan Anemia kehamilan. Yogyakarta: Nuha Medika, 136-137.

Saribu. (2006). Anemia dalam kehamilan dan penanggulangannya. Jakarta: Gramedia Pustaka Utama.

Sinclair, C. (2010). Buku Saku Kebidanan. Jakarta: EGC.

Sugiarti. (2014). Pengaruh Konsumsi Jus Bayam Merah dan Madu terhadap Peningkatan Kadar Hemoglobin Ibu Hamil. Jurnal Akbid Griya Husada, Vol. 2 No.1. http://jurnal.akbid-griyahusada.ac.id/files/ejournal/vol2_no1/e-journal-2-1-2.pdf

Sugiarto, Eko. (2015). Menyusun Proposal Penelitian Kualitatif Skripsi dan Tesis. Yogyakarta: Suaka Media.

Suwita, I Komang, dkk. (2011). Pemanfaatan Bayam Merah (Blitum Rubrum) untuk Meningkatkan Kadar Zat Besi dan Serat pada Mie Kering. Jakarta: Agromix.

Wigati, P. W., \& Firdaus, N. (2018). Pengaruh Pemberian Kombinasi Jus Bayam dan Jambu Biji terhadap Kadar Hemoglobin pada Ibu Hamil di Wilayah Kerja Puskesmas Balowerti Kota Kediri. Journal for Quality in Women's Health, 1(2). 